\title{
Induction of secretion of interleukin-8 from human gastric epithelial cells by heat-shock protein 60 homologue of Helicobacter pylori
}

\author{
HIROYUKI YAMAGUCHI, TAKAKO OSAKI*, NAOTO KURIHARA $†$, MASAKI KITAJIMA†, MASANORI \\ KAI\$, MOTOMICHI TAKAHASHI, HARUHIKO TAGUCHI and SHIGERU KAMIYA
}

Department of Microbiology and *Division of Flowcytometry, Kyorin University School of Medicine, Mitaka, $\uparrow$ Department of Surgery, Keio University School of Medicine, Shinanomachi, Shinjuku and $\$$ Department of Microbiology, Leprosy Research Center National Institute of Infectious Diseases, Higashimurayama-shi, Tokyo, Japan

\begin{abstract}
Escherichia coli cells expressing fusion proteins consisting of $\beta$-galactosidase and bacterial heat-shock protein (HSP) 60 of $E$. coli, Yersinia enterocolitica or Helicobacter pylori were constructed, and designated as HY1, HY2 or HY3, respectively. Fusion proteins prepared from HY2 and HY3 induced secretion of interleukin-8 (IL-8) from human gastric epithelial KATO III cell cultures. On the other hand, the parent strain (E. coli pop2136), PEX (pop2136 transformed by vector) and fusion protein prepared from HY1 did not induce IL-8 secretion from KATO III cells. Other human gastric (MKN45) and non-gastric cell lines (Int 407 and A549) did not secrete IL-8 following treatment with these proteins. These results indicate that $H$. pylori HSP60 induces IL-8 secretion from human gastric cells and the levels of IL-8 differ among the various gastric cell lines, suggesting that HSP60 might be an important virulence factor associated with chronic gastric inflammation following $\boldsymbol{H}$. pylori infection in man.
\end{abstract}

\section{Introduction}

Interleukin-8 (IL-8) is a potential mediator associated with gastric inflammation in patients with Helicobacter pylori infection [1, 2]. Rieder et al. reported that direct contact of $H$. pylori with epithelial cells was needed to induce IL-8 in vivo [3], indicating that a surface component of $H$. pylori might be important. An earlier study demonstrated that the heat-shock protein (HSP) 60 (Hsp B) homologue of $\mathrm{H}$. pylori is located on the bacterial cell surface and is associated with adhesion of H. pylori to human gastric epithelial cells [4]. HSP60 conserved in prokaryotic cells and also eukaryotic cells is thought to facilitate the folding, unfolding and translocation of polypeptides as chaperonins and is associated with chronic inflammation $[5,6]$. Therefore, HSP60 of $H$. pylori is a candidate virulence factor for chronic gastritis induced by $H$. pylori.

The present study examined whether recombinant $H$.

Received 22 Dec. 1998; revised version received 19 Feb. 1999; accepted 21 Feb. 1999.

Corresponding author: Dr H. Yamaguchi (e-mail: hiro-ya@ ta2.so-net.ne.jp). pylori HSP60 expressed by Escherichia coli induces IL-8 secretion from cultured human cell lines.

\section{Materials and methods}

Human cell lines

Human gastric carcinoma cells (KATO III, MKN45) and non-gastric cells (Int407, small intestinal epithelial cells; A549, lung cancer cells) were obtained from the Japanese Cancer Research Resources Bank (JCRB). They were grown at $37^{\circ} \mathrm{C}$ in RPMI1640 containing fetal calf serum $10 \% \mathrm{v} / \mathrm{v}$ in an atmosphere containing $\mathrm{CO}_{2} 5 \%$.

Monoclonal antibody (MAb)

MAb H9 (IgG2a), which reacted with $H$. pylori HSP60, was described previously [7]. The $60-\mathrm{kDa}$ antigen derived from $H$. pylori strain TK1029 was partially purified by extraction from SDS-PAGE separating gel. BALB/c mice were immunised intraperitoneally (i.p.) with the antigen mixed with Freund's complete adjuvant (Difco Laboratories, Detroit, MI, USA), three times at an interval of 10 days. Ten days after the last i.p. injection, the mice were given the 
partially purified antigen intravenously. Then 3 days after the last immunisation, spleens were removed for cell fusion with mouse myeloma cells (P3-X63-Ag8$\mathrm{U1)}$. The hybridoma cells producing MAb that reacted with the affinity-purified $H$. pylori HSP60 and the sonicated MKN45 cells (human gastric cancer cell line) in ELISA were collected. The hybridoma cells with apparent specific antibody production were cloned by limiting dilution. Cells $10^{6}$ were inoculated i.p. into a BALB/c mouse pretreated i.p. with pristane (Wako Pure Chemical) $0.5 \mathrm{ml}, 4$ days before the inoculation of the cells and ascites fluids were obtained from the mouse $c .2$ weeks later. The immunoglobulins in the ascites fluids were purified with the ImmunoglobulinEasy-Separation kit (Pharmacia Biotechnology, Tokyo, Japan). The purified MAb was used for affinity chromatography and immunoblotting analysis.

\section{Affinity-purified H. pylori HSP60}

HSP60 was affinity-purified with specific MAb recognising $H$. pylori HSP60 from $H$. pylori strain TK1029 ( $\operatorname{cag} A$ and $v a c A$ positive) isolated from a patient with gastric ulcer as described above [8].

\section{Construction of E. coli expressing H. pylori HSP60}

DNA fragments encoding $E$. coli GroEL, Yersinia enterocolitica HSP60 or $H$. pylori HSP60 were amplified from bacterial strains by PCR as indicated in Table 1. The primer sets used were as follows: upstream 5'-GAATTCATGGCAGCTAAAGACGTAAA -3', downstream 5'-GAATTCTTACATCATGCCGCCCTAGC-3' (E. coli and Y. enterocolitica); upstream 5'-GAATTCATGGCAAAAGAAATCAAATT-3', downstream 5'-GAATTCTTACATCATGCCGCCCTAGC (H. pylori). The recognition sequences GAATTC with $E c o$ RI restriction endonuclease were added on both sides of $5^{\prime}$-upstream and $3^{\prime}$-downstream for subcloning the resultant cDNA into a plasmid $\mathrm{pEX}$. The resultant cDNA was integrated into a plasmid $\mathrm{pEX}$ capable of producing a fused protein with $\beta$-galactosidase [9]. The constructed plasmids were transformed into $E$. coli pop2136. The bacteria were cultivated at $30^{\circ} \mathrm{C}$ and then shifted to $42^{\circ} \mathrm{C}$ for $2 \mathrm{~h}$ to induce the expression of the recombinant protein (fusion protein). Bacterial pellets were stored at $-80^{\circ} \mathrm{C}$ until their use in SDS-PAGE. Fusion proteins expressed by $\mathrm{pEX}$ vector in $E$. coli pop2136 containing the cIts 857 repressor have been shown to account for $>30 \%$ of the total SDS-extracted bacterial proteins [10]. All sequences of the amplified cDNA inserted into plasmid pEX were confirmed by direct sequencing. The bacteria were cultivated at $30^{\circ} \mathrm{C}$ and then shifted to $42^{\circ} \mathrm{C}$ for $2 \mathrm{~h}$ to induce the expression of the recombinant protein (fusion protein). Bacterial pellets were stored at $-80^{\circ} \mathrm{C}$ until use in SDS-PAGE.

\section{Preparation of fusion proteins}

The fusion proteins were prepared as described previously [10]. Each E. coli strain (HY1, HY2 or HY3) harbouring $\mathrm{pHY} 1$, pHY2 or pHY3 encoding hsp60 of E. coli, $Y$. enterocolitica or $H$. pylori, respectively, was sonciated with a Sonifer 250 (Branson, NY, USA) and then insoluble fractions were collected by centrifugation at $10000 \mathrm{~g}$. The pellet (insoluble fraction containing fusion protein) was incubated in $50 \mathrm{mM}$ Tris- $\mathrm{HCl}, \mathrm{pH} 8.0$, containing $1 \mathrm{mM}$ EDTA, $1 \mathrm{mM}$ DTT and $8 \mathrm{M}$ urea for $1 \mathrm{~h}$ at $37^{\circ} \mathrm{C}$. After the solutions containing fusion protein had been dialysed against PBS and sterilised by filtration, they were used for induction of IL- 8 from cultured cell lines KATO III (human gastric cancer cells), MKN45 (human gastric cancer cells), Int407 (human small intestinal cells) and A549 (human lung cancer cells). Parental strains of E. coli pop2136 and PEX (pop2136 harbouring $\mathrm{pEX}$ ) treated as described above were used as negative controls.

\section{SDS-PAGE and immunoblotting}

SDS-PAGE with acrylamide $8 \% \quad \mathrm{w} / \mathrm{v}$ gels was performed as described by Laemmli [11]. Each bacterial pellet stored at $-80^{\circ} \mathrm{C}(1 \mathrm{ml}$ of cultured

Table 1. Plasmids and bacterial strains used

\begin{tabular}{|c|c|}
\hline Plasmid or bacterial strain & Relevant characteristics or purpose for use \\
\hline \multicolumn{2}{|l|}{ Plasmid } \\
\hline $\mathrm{pEX}$ & Protein expression vector \\
\hline pHY1 & groEL of $E$. coli cloned into $\mathrm{pEX}$ \\
\hline pHY2 & hsp60 of $Y$. enterocolitica cloned into $\mathrm{pEX}$ \\
\hline pHY3 & hsp60 of $H$. pylori cloned into $\mathrm{pEX}$ \\
\hline \multicolumn{2}{|l|}{ Bacterial strain } \\
\hline H. pylori TK1029 (genotype: $\operatorname{cag} A+$, vac $A+$ ) & Used for amplification of $H$. pylori HSP60-encoding gene by PCR \\
\hline & Used for purification of $H$. pylori HSP 60 by affinity column with $\mathrm{MAb}^{*} \mathrm{H} 20$ \\
\hline Y. enterocolitica ZM20 $0: 3$ & Used for amplification of $Y$. enterocolitica HSP60-encoding gene by PCR \\
\hline E. coli pop 2136 & Used for amplification of E. coli GroEL-encoding gene by PCR \\
\hline & Parent strain for transformation \\
\hline PEX & E. coli harbouring $\mathrm{pEX}$ \\
\hline HY1 & E. coli harbouring $\mathrm{pHY} 1$ \\
\hline HY2 & E. coli harbouring pHY2 \\
\hline HY3 & E. coli harbouring pHY3 \\
\hline
\end{tabular}

${ }^{*}$ MAb recognising H. pylori HSP60. 
bacterial cells expressing fusion proteins) was suspended in $300 \mu \mathrm{l}$ of PBS. The bacterial solutions were mixed with $300 \mu \mathrm{l}$ of sample buffer $(\mathrm{pH} 6.8 ; 0.012 \mathrm{M}$ Tris, glycerol $20 \% \mathrm{v} / \mathrm{v}, 0.015 \mathrm{M} \mathrm{SDS}$ and $0.4 \mathrm{mM} 2-$ mercaptoethanol). The solutions were heated for $10 \mathrm{~min}$ at $100^{\circ} \mathrm{C}$. Finally, $20 \mu \mathrm{l}$ of the bacterial lysates were loaded into each lane of a separating $8 \%$ gel. Immunoblot analysis was done as described by Towbin et al. [12]. After electrophoresis, the separated proteins were transferred to nitrocellulose membranes (Schleiher and Schuell, Dassel, Germany) at $0.25 \mathrm{~A}$ overnight. After blocking with phosphate-buffered saline (PBS; $\mathrm{pH}$ 7.4) containing skimmed milk $1 \% \mathrm{w} / \mathrm{v}$ (Yukijirushi Nyugyo, Sapporo, Japan) (PBS-S) for $1 \mathrm{~h}$ at room temperature, the membranes were treated for $1 \mathrm{~h}$ with MAb H9 diluted to $1 \mu \mathrm{g} / \mathrm{ml}$ with PBS-S. They were then incubated for $1 \mathrm{~h}$ with goat anti-mouse $\mathrm{IgC}$ peroxidase conjugate diluted 1 in 500 with PBS-S. Immunoblots were developed with $50 \mathrm{mM}$ Tris- $\mathrm{HCl}$ buffer (pH 7.4) containing $\mathrm{H}_{2} \mathrm{O}_{2} \quad 0.12 \% \mathrm{v} / \mathrm{v}$ and $1 \mathrm{mM}$ 3,3'-diaminobenzidine tetrahydrochloride (Dojinkagaku, Kumamoto, Japan).

\section{Detection of $I L-8$ secretion}

Established cultured human cells $\left(3 \times 10^{4}\right)$ were incubated in RPMI1640 containing fetal bovine serum $10 \%$ $\mathrm{v} / \mathrm{v}$ with fusion proteins or control cell lysate $(1.25-150 \mu \mathrm{g} / \mathrm{ml})$ for $24-96 \mathrm{~h}$ at $37^{\circ} \mathrm{C}$. After cultivation, the amount of IL-8 in each culture supernate was measured by a sandwich-ELISA, with a commercially available ELISA kit (Cytoscreen Human IL-8; Bio Source International, CA, USA).

\section{Statistical analysis}

The statistical significance of the differences was assessed by the Friedman test.

\section{Results}

\section{Profiles of the prepared fusion proteins}

The profiles of the prepared fusion proteins were examined by SDS-PAGE and immunoblotting with MAb H9 directed to bacterial HSP60 [8]. As shown in Fig. 1, each E. coli (HY1, lane 4; HY2, lane 5; HY3, lane 6) expressing bacterial HSP60 was confirmed by SDS-PAGE as being constructed. All fusion proteins with mol. wts of $c$. $180 \mathrm{kDa}$ (lanes 9-11) were recognised by MAb H9 directed to bacterial HSP60 [7]. The band corresponding to a $60-\mathrm{kDa}$ molecule in all samples recognised by MAb H9 was thought to be native GroEL from the parent $E$. coli strain, and especially in lanes loaded with the fusion proteins, the intensity of brands was stronger than that in the other lanes. This phenomenon could be explained by the fact that the overexpression of foreign antigen such as the fusion protein in $E$. coli enhances production of native GroEL to eliminate the foreign protein [10].

\section{Detection of IL-8 secretion from established human cell lines by recombinant $H$. pylori HSP60}

As shown in Fig. 2, IL-8 secretion was induced from human gastric KATO III cells by HY3 (fusion protein of $H$. pylori HSP60). The amounts of IL-8 detected after cultivation with $150 \mu \mathrm{g}$ of fusion protein $/ \mathrm{ml}$ for $24,48,72$ and $96 \mathrm{~h}$, were $2862,2884,3068$ and

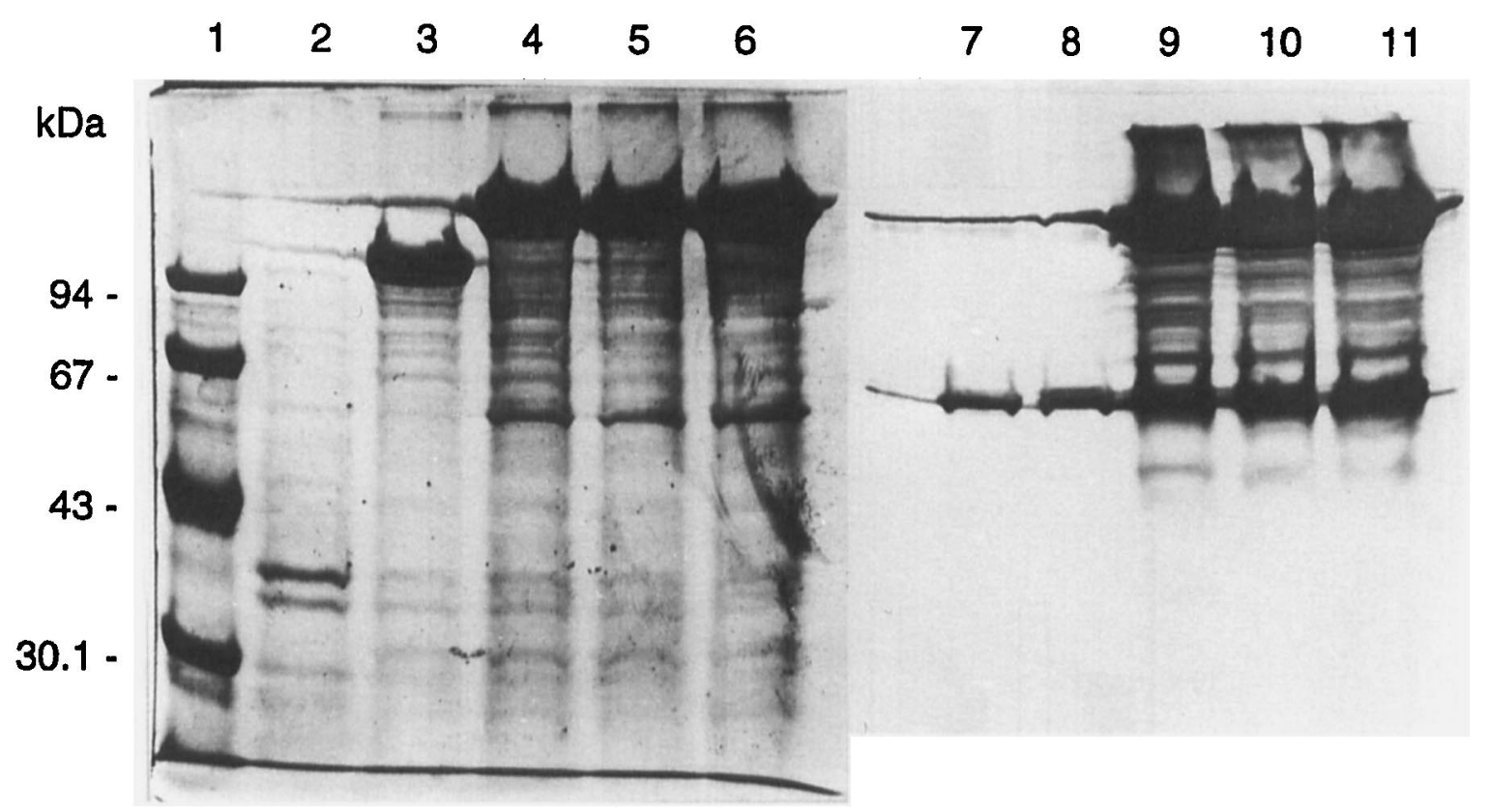

Fig. 1. Profiles of SDS-PAGE (lanes 1-6) and immunoblotting with MAb H9 recognising bacterial HSP60 (7-11) of fusion proteins prepared by treatment with $8 \mathrm{M}$ urea. The prepared antigens were loaded as follows: lanes 2 and 7 , control (pop2136); 3 and 8, PEX; 4 and 9, HY1; 5 and 10, HY2; 6 and 11, HY3. 

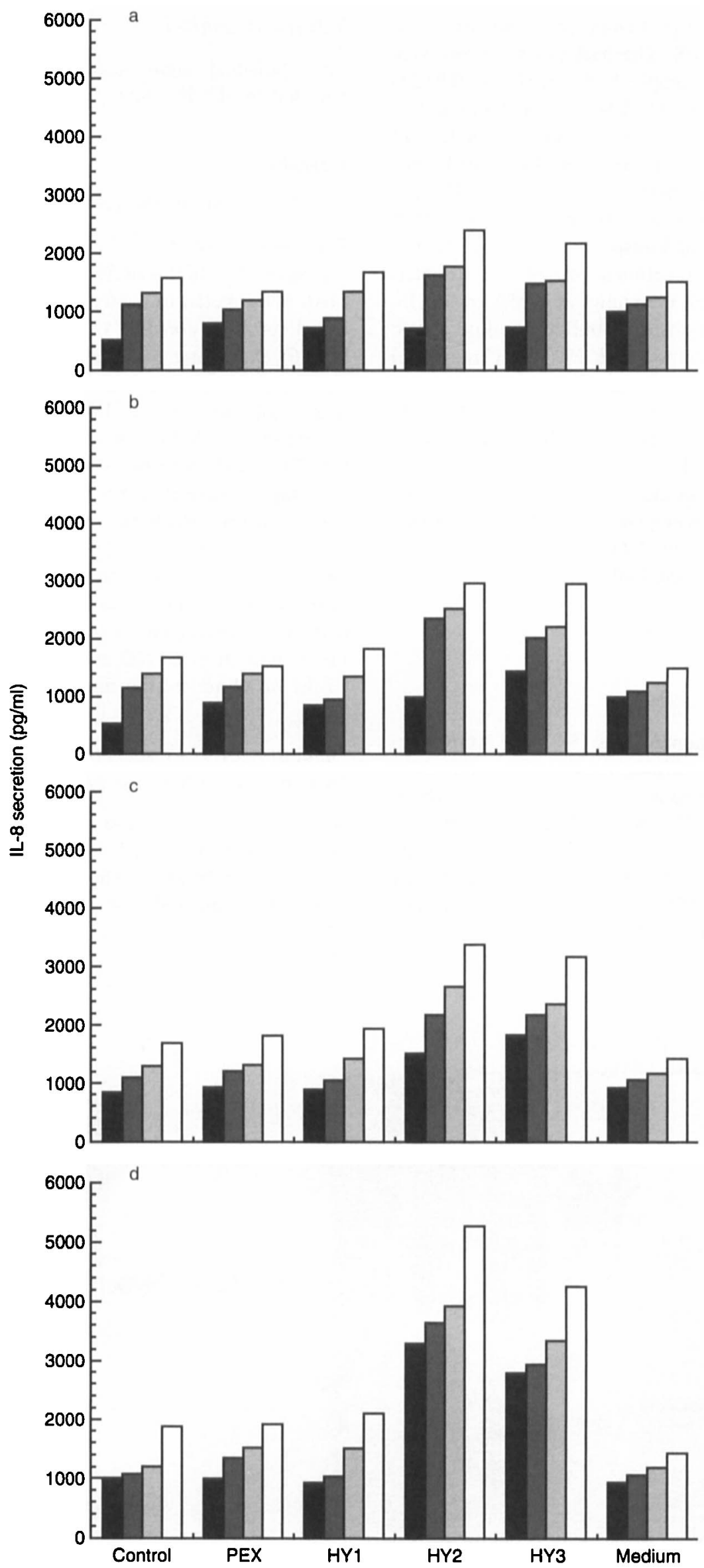

Fig. 2. IL-8 secretion from human gastric carcinoma cell line (KATO III) induced by fusion protein PEX, HY1, HY2 and HY3. Concentrations $(\mu \mathrm{g} / \mathrm{ml})$ of the prepared antigens used were $1.25(\mathbf{a}), 6(\mathbf{b}), 30$ (c) and 150 (d) and IL-8

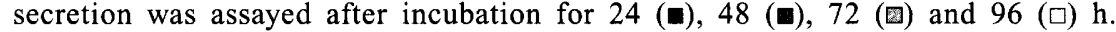


$4321 \mathrm{pg} / \mathrm{ml}$, respectively. Similarly, HY2 (fusion protein of $Y$. enterocolitica HSP60) also induced a level of secretion of IL-8 as high as that induced by HY3. Furthermore, a significant dose-response was observed when HY2 and HY3 were used in IL-8 induction experiments $(\mathrm{p}<0.01)$. Neither HY1 (fusion protein of E. coli GroEL), PEX nor E. coli pop 2136 induced production of significant amounts of IL-8. In contrast, HY3 did not induce IL-8 secretion from other cell lines such as MKN45, Int407 and A549 cells (Table 2). These results indicate that recombinant $H$. pylori HSP60 induces IL-8 secretion from KATO III cells, but not from other cell lines such as MKN45, Int407 and $\mathrm{A} 549$.

\section{Discussion}

The induction of IL-8 secretion from KATO III cells with fusion proteins containing $H$. pylori or $Y$. enterocolitica HSP60, but not with E. coli GroEL was observed in the present study. Amino-acid sequences of $H$. pylori HSP60, Y. enterocolitica HSP60 and E. coli GroEL have been reported previously [13-15]. The similarities of the amino-acid sequences among these junior proteins were as follows: $55.4 \%$ for $H$. pylori HSP60 versus $Y$. enterocolitica HSP $60 ; 55.9 \%$ for $H$. pylori HSP60 versus $E$. coli GroEL; and $88.2 \%$ for $Y$. enterocolitica HSP60 versus E. coli GroEL. As shown in Fig. 3, the amino-acid regions that include an identical amino-acid position in H. pylori HSP60 and Y. enterocolitica HSP60 but not in E. coli GroEL might be associated with IL-8 induction from KATO III cells.

The induction of IL-8 secretion from KATO III cells but not from another gastric cell line (MKN45) by $H$. pylori HSP60 was observed. Aihara et al. [16] have reported that the secretion of IL-8 by live $H$. pylori was different in various human gastric cancer cell lines (MKN45, MKN1, MKN28, MKN74 and KATO III). A previous study reported that $H$. pylori HSP60 was associated with adhesion of $H$. pylori to human gastric epithelial cells [4]. Huesca et al. reported that surface HSPs 60 and 70 of $H$. pylori are associated with attachment to human gastric epithelial cells by binding to the receptor, sulphated glycolipid [17]. These reports suggest that the different amounts of sulphated glycolipid on the various epithelial cells might also be associated with differences in IL-8 induction.

It has been reported that direct contact of $H$. pylori with epithelial cells was associated with the induction of IL-8 secretion [3]. Censini et al. reported an association of various Cag proteins encoded by the cag pathogenicity island of $H$. pylori with IL-8 secretion from gastric epithelial cells [18]. Huang et al. [19] have shown that water-soluble extract containing bacterial surface components such as urease, FlaAB, HSPs, membrane proteins and lipopolysaccharide (LPS) induced IL-8 secretion from gastric epithelial cell lines, AGS and KATO III. They also indicated that a urease-negative mutant and a non-motile mutant did not differ from the parent $H$. pylori strain with respect to IL-8 induction [19]. Furthermore, it has been reported recently that $H$. pylori LPS did not induce IL-8 production from AGS cells [20]. It is possible that porin protein is involved in the induction of IL-8 production from gastric epithelial cells, as $H$. pylori porins have been reported to stimulate human monocytes and lymphocytes to release various cytokines such as TNF- $\alpha$, IL-6 and IL-8 [21]. Recently, Galdero et al. [22] reported that GroEL and DnaK of E. coli induced both secretion of cytokines (TNF- $\alpha$, IL- 6 and IL-8) from human monocytes and lymphocytes and expression of adhesion molecule in endothelial cells.

The present study demonstrated for the first time that HSP60 or H. pylori induced IL-8 secretion from gastric epithelial cells, suggesting that HSP 60 might be an important virulence factor associated with chronic gastric inflammation following $H$. pylori infection. The mechanism by which IL-8 was induced by $H$. pylori HSP60 and the reason why the induction level of IL-8 was different depending on the gastric cells used are not yet understood.

Table 2. Induction of IL-8 secretion from gastric and non-gastric epithelial cells by prepared antigens*

\begin{tabular}{|c|c|c|c|c|c|c|c|c|c|c|c|c|}
\hline \multirow{4}{*}{$\begin{array}{l}\text { Prepared } \\
\text { antigen } \\
\text { added to } \\
\text { cultures } \\
(150 \mu \mathrm{g} / \mathrm{ml})^{\dagger}\end{array}$} & \multicolumn{12}{|c|}{ Mean IL-8 secretion $(\mathrm{pg} / \mathrm{ml})^{*}$ from } \\
\hline & \multirow{2}{*}{\multicolumn{4}{|c|}{$\begin{array}{l}\text { Gastric epithelial cell line } \\
\text { MKN45 }\end{array}$}} & \multicolumn{8}{|c|}{ Non-gastric epithelial cell lines } \\
\hline & & & & & \multicolumn{4}{|c|}{ Int 407} & \multicolumn{4}{|c|}{ A549 } \\
\hline & $24 \mathrm{~h}$ & $48 \mathrm{~h}$ & $72 \mathrm{~h}$ & $96 \mathrm{~h}$ & $24 \mathrm{~h}$ & $48 \mathrm{~h}$ & $72 \mathrm{~h}$ & $96 \mathrm{~h}$ & $24 \mathrm{~h}$ & $48 \mathrm{~h}$ & $72 \mathrm{~h}$ & $96 \mathrm{~h}$ \\
\hline pop2136 & 364 & 375 & 615 & NT & 37 & 34 & 86 & NT & 1335 & 1421 & 1661 & NT \\
\hline PEX & 440 & 680 & 653 & 1112 & 12 & 17 & 59 & 147 & 1159 & 1260 & 1230 & 1789 \\
\hline HY1 & 309 & 380 & 444 & 793 & 13 & 16 & 36 & 108 & 997 & 1159 & 1466 & 1841 \\
\hline HY2 & 472 & 618 & 820 & 934 & 13 & 20 & 56 & 162 & 1381 & 1442 & 1688 & 1954 \\
\hline HY3 & 342 & 417 & 529 & 966 & 20 & 26 & 67 & 203 & 1158 & 1228 & 1339 & 1589 \\
\hline Medium & 48 & 70 & 89 & 144 & 24 & 43 & 94 & 158 & 543 & 633 & 751 & 877 \\
\hline
\end{tabular}

NT, not tested.

*The results shown are the average of duplicate assays

${ }^{\dagger}$ The antigens were prepared as described in the text. 
HPHSP6O AA 1:M-AKEIKFSDSARNLLFEGVROLHDAVKVTMGPRGRNVLIQKSYGAPSI TKDGVSVAKEI 59 YeHSP60 AA 1:MAAKDVKFGNDARIKMLRGVNILADAVKVTLGPKGRNVVLDKSFGSPTITKDGVSVAREI 60 EcGroEL AA 1:MAAKDVKFGNDARVKMLRGVNVLADAVKVTLGPKGRNVVLDKSFGAPTITKDGVSVAREI 60 *** *** *** **********************************

HPHSP60 AA 60:ELSCPVANMGAQLVKEVASKTADAAGDGTTTATVLAYSIFKEGLRNITAGANPIEVKRGM 119 YeHSP60 AA 61:ELEDKFENMGAQMVKEVASKANDAAGDGTTTATVLAQSIITEGLKAVAAGMNPMDLKRGI 120 EcGroEL AA 61:ELEDKFENMGAQMVKEVASKANDAAGDGTTTATVLAQAIITEGLKAVAAGMNPMDLKRGI 120 ** ************************************* *********

HPHSP60 AA 120:DKAAEAIINELKKASKKVGGKEEITQVATISANSDHNIGKLIADAMEKVGKDGVITVEEA 179 YeHSP60 AA 121:DKAVIAAVEELKKLYYVCSDSKAIAQVGTISANSDSTVGELIAQANEKVGKEGVITVEEG 180 EcGroEL AA 121:DKAVTAAVEELKALSVPCSDSKAIAQVGTISANSDETVGKLIAEAMDKVGKEGVITVEDG 180 ***** * **** ********k*k**********************

HPHSP60 AA 180:KGIEDELDVVEGMQFDRGYLSPYFVTNAEKMTAQLDNAYILLTDKKISSMKDILPLLEKT 239 YeHSP60 AA 181:PGLQDELDVVEGMQFDRGYLSPYFINKPETGSIELESPFILLADKKISNIREMLPVLEAV 240 EcGroEL AA 181:TGLQDELDVVEGMQFDRGYLSPYF I NKPETGAVELESPFILLADKKISN IREMLPVLEAV 240

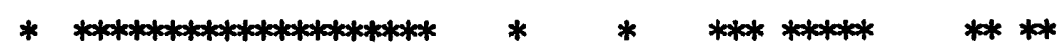

HpHSP60 AA 240:MKEGKPLLIIAEDIEGEALTTIVVNKLRGVLNI AAVKAPGFGDRRKEMLKDIAILTGGQV 299 YeHSP60 AA 241:AKAGKPLLIIAEDVEGEALATLVVNTMRGIVKVAAVKAPGFGDRRKAMLQD IATLTVGTV 300 EcGroEL AA 241:AKAGKPLLIIAEDVEGEALATAVVNTIRGIVKVAAVKAPGFGDRRKAMLQDIATLTGGTV 300 *********************** ** ************************

HPHSP60 AA 300:ISEELGLSLENAEVEFLGKAGRIVIDKDNTTIVDGKGHSDDVKDRVAQIKTQIASTTSDY 359 YeHSP60 AA 301: ISEEI GLELEKTTLEDLGQAKRVVINKDTTIIIDGVGDEAAIQGRVTQIRQQIEEATSDY 360 ECGroEL AA 301:ISEE IGMELEKATLEDLGQAKRVVINKDTTTIIDGVGEEAAIQGRVAQIRQQIEEATSDY 360

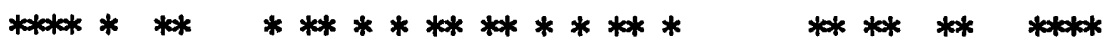

HPHSP60 AA 360:DKEKLQERLAKLSGGVAVIKVGAASEVEMKEKKDRVDDALSATKAAVEEGIVIGGGAALI 419 YeHSP60 AA 361:DKEKLQERVAKLAGGVAVIKVGAATEVEMKEKKARVEDALHATRAAVEEGVVAGGGVALI 420 EcGroEL AA 361:DREKLQERVAKLAGGVAVIKVGAATEVEMKEKKARVEDALHATRAAVEEGVVAGGGVALI 420

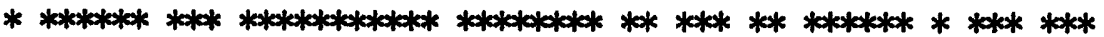

HPHSP60 AA 420:R-AA-QK-VHL-NLHDDEKVGYEIIIMRAIKAPLAQIAINAGYDGGVVVNEVEKHEGHFGF 475 YeHSP60 AA 421:RAASAITAAGLKGDNEDQNVGIKVALRAMESPLRQIVVNAGEEASVI ANNVKAGSGSYGY 480 ECGroEL AA 421:RVASKL--ADLRGQNEDQNVG IKVALRAMEAPLRQIVLNCGEEPSVVANTVKGGDGNYGY 478

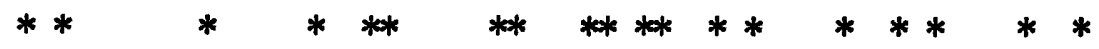

HPHSP60 AA 476: NASNGKYVDMFKEGIIDPLKVERIALQNAVSVSSLLLTTEATVHEIKEEKATPAMPDMGG 535 YeHSP60 AA 481:NAYSEEYGDMIAMGILDPTKVTRSALQYAASIAGLMITTECMITDLPRDDKGADMG-AGG 539 EcGroEL AA 479:NAATEEYGNMIDMGILDPTKVTRSALQYAASVAGLMITTECMVTDLPKND-AADLGAAGG 537

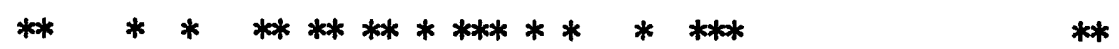

Fig. 3. Homology of amino-acid sequences among H. pylori HSP60 (HpHSP60 AA). Y. enterocolitica HSP60 (YeHSP60 AA) and $E$. coli GroEL (EcGroEL AA). Homologous sequences are indicated by an asterisk. The positions of amino acids which are homologous between $H$. pylori HSP60 and $Y$. enterocolitica HSP60 but not $E$. coli GroEL are shown as boxes. 


\section{References}

1. Gionchetti P, Vaira D, Campieri $\mathrm{M}$ et al. Enhanced mucosal interleukin-6 and -8 in Helicobacter pylori-positive dyspeptic patients. Am J Gastronenterol 1994; 89: 883-887.

2. Yoshida N, Granger DN, Evans DJ et al. Mechanisms involved in Helicobacter pylori-induced inflammation. Gastroenterology 1993; 105: 1431-1440.

3. Rieder G, Hatz RA, Moran AP, Walz A, Stolte M, Enders G. Role of adherence in Interleukin-8 induction in Helicobacter pylori-associated gastritis. Infect Immun 1997; 65: 3622-3630.

4. Yamaguchi $\mathrm{H}$, Osaki $\mathrm{T}$, Kurihara $\mathrm{N}$ et al. Heat-shock protein 60 homologue of Helicobacter pylori is associated with adhesion of $H$. pylori to human gastric epithelial cells. $J$ Med Microbiol 1997; 46: 825-831.

5. Ellis RJ. The molecular chaperone concept. Semin Cell Biol 1990; 1: 1-9.

6. Young, DB. Chaperonins and the immune response. Semin Cell Biol 1990; 1: 27-35.

7. Yamaguchi H, Osaki T, Taguchi $H$, Hanawa T, Yamamoto $T$, Kamiga S. Production and characterisation of monoclonal antibodies to heat-shock protein 60 of Helicobacter pylori. $J$ Med Microbiol 1997; 46: 819-824.

8. Yamaguchi $\mathrm{H}$, Osaki $\mathrm{T}$, Taguchi $\mathrm{H}$ et al. Growth inhibition of Helicobacter pylori by monoclonal antibody to heat-shock protein 60. Microbiol Immunol 1997; 41: 909-916.

9. Stanley KK, Luzio JP. Construction of a new family of high efficiency bacterial expression vectors: identification of cDNA clones coding for human liver proteins. EMBO $J 1984$; 3 : 1429-1434.

10. Amrein KE, Takacs B, Stieger M, Molnos J, Flint NA, Burn P. Purification and characterization of recombinant human p50csk protein-tyrosine kinase from an Escherichia coli expression system overexpressing the bacterial chaperones GroES and GroEL. Proc Natl Acad Sci USA 1995; 92: 1048-1052.

11. Laemmli UK. Cleavage of structural proteins during the assembly of the head of bacteriophage T4. Nature 1970 ; 227: $680-685$.

12. Towbin H, Staehelin T, Gordon J. Electrophoretic transfer of proteins from polyacrylamide gels to nitrocellulose sheets: procedure and some applications. Proc Natl Acad Sci USA 1979; 76: 4350-4354.

13. Hemmingsen SM, Woolford C, van der Vies SM et al. Homologous plant and bacterial proteins chaperone oligometric protein assembly. Nature 1988; 33: 330-334.

14. Macchia G, Massone A, Burroni D, Covacci A, Censini S, Rappuoli R. The Hsp60 protein of Helicobacter pylori: structure and immune response in patients with gastroduodenal diseases. Mol Microbiol 1993; 9: 645-652.

15. Yamamoto $\mathrm{T}$, Miura $\mathrm{H}$, Ohsumi $\mathrm{K}$ et al. Cloning and nucelotide sequence analysis of immunodominant heat-shock protein of Yersinia entercolitica. Res Microbiol 1993; 144: 691-701.

16. Aihara M, Tsuchimoto D, Takizawa $\mathrm{H}$ et al. Mechanisms involved in Helicobacter pylori-induced interleukin-8 production by a gastric cancer cell line, MKN45. Infect Immun 1997; 65: $3218-3224$.

17. Huesca M, Borgia S, Hoffman, P, Lingwood CA. Acidic $\mathrm{pH}$ changes receptor binding of Helicobacter pylori: a binary adhesion model in which surface heat-shock (stress) proteins mediate sulfatide recognition in gastric colonization. Infect Immum 1996; 64: 2643-2648.

18. Censini S, Lange $\mathrm{C}, \mathrm{Xiang} \mathrm{Z}$ et al. cag, a pathogenicity island of Helicobacter pylori, encodes type I-specific and diseaseassociated virulence factors. Proc Natl Acad Sci USA 1996; 93: $14648-14653$.

19. Huang J, O'Toole PW, Doig P, Trust TJ. Stimulation of interleukin-8 production in epithelial cell lines by Helicobacter pylori. Infect Immun 1995; 63: 1732-1738.

20. Sharma SA, Tummuru MKR, Miller GG, Blaser Mj. Interleukin-8 response of gastric epithelial cell lines to Helicobacter pylori stimulation in vitro. Infect Immun 1995; 63: $1681-1687$.

21. Tufano MA, Rossano F, Catalanotti $P$ et al. Immunobiological activities of Helicobacter pylori porins. Infect Immun 1994; 62: 1392-1399.

22. Galdiero M, Cipollaro de l'Ero G, Marcatili A. Cytokine and adhesion molecule expression in human monocytes and endothelial cells stimulated with bacterial heat shock proteins. Infect Immun 1997; 65: 699-707. 